liaison rather than action body. It consists of membership from a wide range of organizations in the forest sector including government, industry, academia and labour.
Canada qui se réunit deux fois par année pour identifier et discuter des sujets importants en foresterie et d'intérêts communs. II est formé de représentants de diverses organisations du secteur forestier, y compris le gouvernement, l'industrie, le milieu académique et le monde du travail.

\title{
Letters/Lettres
}

\section{Logging Waste The Other Side of the Story}

\section{Re: I.D. Thompson's Letter in The Forestry Chronicle, June 1988.}

Ian Thompson also should be a little more factual. In his letter to Mr. Zimmerman he states that if MacMillan Bloedel stopped wasting wood the old growth might last more than 14 years. Old growth will still be logged 50 years from now given no drastic changes in the inventory; the FEPA study was far too pessimistic. Mr. Thompson also makes the basic mistake of assuming that because you waste timber in the logging process, more forest will be cut. Not so, as it makes no difference to the level of cut whether all or none of the wood is wasted. Scaled volume plus the residual (wasted) volume equals the annual allowable cut (AAC).

Residue (waste) on the coast is measured so that there is an accurate accounting of the total cut, and control is maintained to avoid overcutting in comparison to the AAC. Using the MacMillan Bloedel figures from the Queen Charlotte Islands where $27 \%$ of the volume was left in the woods then only $73 \%$ can be produced. The T.M. Thomson investigation of the waste in the Queen Charlottes showed that the residue was accurately measured and indicated that the company method of measuring residue was more accurate than the provincial method and measured more residue. Residue is everything in the inventory that is left behind - sound uneconomic logs, sound volume in cull logs, bucked out crooks, slivers and chunks resulting from breakage, high stumps, bucking waste, etc. Also, any sound economic logs left behind are included.

Previously, a licencee was required to cut $100 \%$ of the annual allowable cut $\pm 10 \%$ over a five-year period or face penalties, so there was considerable effort to achieve the AAC. Under the new legislation, a licencee has to balance to $100 \%$ over a five-year period or lose cut if there is an undercut

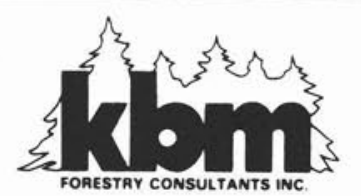

360 mooney street thunder bay, ontario P7B 5R4

$$
\begin{aligned}
& \text { REFORESTATION EQUIPMENT } \\
& - \text { Sales Service Parts Repair } \\
& \text { REGENERATION \& SITE PREPARATION } \\
& - \text { Contract Assessment Consulting } \\
& \text { Tele 807-344-0811 telex 073-4522 } \\
& \text { Toll free 1-800-465-3001 }
\end{aligned}
$$

situation. This will bring even more pressure on licencees to meet the $100 \%$ and is not an incentive to preserve timber.

To be completely factual, it is necessary to point out that:

- As far as I know, the government has not levied penalties for cutting below the AAC for reasons beyond the control of a licencee. These penalties are at the discretion of the Minister, which is always uncertain.

- The high levels of waste in the Queen Charlottes continued beyond the survival mode of 1983 to 1985 but it should be recognized that residue is measured late. Ninety-five percent of the 1986 residue in the QC Division was measured on areas logged in 1983 to 1985.

These are the facts as I see them. There is another side to the situation and I wonder whether Mr. Thompson or any of your other readers would have decided to save the "waste" and ignore the human side? There were nearly 400 jobs, company and contractors, in three small, isolated communities almost wholy dependent on logging, riding on the decision of either operate at a profit and waste the uneconomic logs, or remain shut down for an unknown length of time during a period when corporate losses were running at over $\$ 100$ million annually. As a MacMillan Bloedel employee, working in the Nanaimo Region at the time, I know how difficult it was for the people making those decisions in 1982. As a forester, I deplored the waste but as a human being, even with hindsight, I cannot disagree with the decision to start operating again and leave the uneconomic logs.

Yours truly

G. von Westarp

R.R. \#1, Site \#1

Gabriola, B.C. VOR $1 \times 0$

\section{Woodlot Service (1978) Ltd.}

"All Matters Pertaining to Forestry"

GORDON B. YOUNG, B.Sc.F., M.F.

Registered Professional Forester

320 Maple Street

Fredericton, N.B.

Bus.: 506-458-9366

E3A 3R4

Home: $506-472-7721$ 